Zeszyty Naukowe Szkoły Głównej Gospodarstwa Wiejskiego w Warszawie Problemy Rolnictwa Światowego tom 17 (XXXII), zeszyt 3, 2017: 60-70

DOI: 10.22630/PRS.2017.17.3.53

\author{
Małgorzata Dolata ${ }^{1}$ \\ Uniwersytet Przyrodniczy w Poznaniu
}

\title{
Infrastruktura jako instrument poprawy regionalnej konkurencyjności obszarów wiejskich
}

\section{Infrastructure as an Instrument for Improving Regional Competitiveness of Rural Areas}

\begin{abstract}
Synopsis. W pracy zaprezentowano podstawowe zagadnienia związane z konkurencyjnością regionalną obszarów wiejskich oraz infrastrukturą. Głównym celem opracowania było przedstawienia znaczenia infrastruktury jako jednego z najistotniejszych czynników konkurencyjności obszarów wiejskich. Infrastruktura stanowi element potencjału konkurencyjności terytorialnej, a wyposażenie infrastrukturalne wpływa na kształtowanie poziom tzw. atrybutów konkurencyjności. Wskazano również na rolę jaką Unia Europejska przypisuje infrastrukturze jako instrumentowi prokonkurencyjnemu. Wyniki przeprowadzonych badań potwierdziły, że od czasu wejścia Polski do struktur Unii Europejskiej na obszarach wiejskich miał miejsce systematyczny rozwój ich wyposażenia infrastrukturalnego. Szczególnie szybkie tempo wzrostu charakteryzowało rozwój systemu odprowadzania i oczyszczania ścieków.
\end{abstract}

Slowa kluczowe: infrastruktura, konkurencyjność regionu, obszary wiejskie

Abstract. The paper presents basic issues related to regional competitiveness of rural areas and infrastructure. The main purpose of the study was to present the importance of infrastructure as one of the most important factors for the competitiveness of rural areas. Infrastructure is an element of territorial competitiveness potential, and infrastructural equipment influences the shaping of the level the so-call attributes of competitiveness. It also indicated the role that the European Union attributes to infrastructure as a pro-competitive instrument. The results of the conducted research confirmed that since Poland's accession to the structures of the European Union in rural areas a systematic development of their infrastructural facilities took place. Particularly fast growth rate was characterized by the development of sewerage and waste water treatment system.

Key words: infrastructure, competitiveness of the region, rural areas

\section{Wstęp}

Rola obszarów wiejskich $\mathrm{w}$ strukturach regionalnych wynika $\mathrm{z}$ ich znaczącego potencjału w różnych obszarach życia społeczno-gospodarczego. Uwarunkowanie to sprawia, że obszary te mogą być nośnikami rozwoju i mogą determinować uzyskiwanie przez jednostki terytorialne wyższych pozycji konkurencyjnych. Przy czym należy zauważyć, że znaczenie obszarów wiejskich w budowaniu i zwiększaniu konkurencyjności regionalnej może się znacznie różnić, ze względu na ich zróżnicowanie pod względem poziomu rozwoju gospodarczego, jakość życia, czy podatności na zmiany.

Jednym z najistotniejszych, a jednocześnie niezbędnych i najbardziej efektywnych czynników rozwoju obszarów wiejskich, a więc i rozwoju regionalnego jest infrastruktura.

${ }^{1}$ dr, Katedra Ekonomii UP w Poznaniu, ul. Wojska Polskiego 28, 60-637 Poznań, e-mail: dolata@up.poznan.pl 
Wynika to z jej wyjątkowych cech (trwałości, związku z obszarem, powszechności dostępu) oraz funkcji jakie pełni (lokalizacyjną, lokacyjną, integracyjną, aktywizacyjną). Ponadto oddziaływanie infrastruktury posiada określony zasięg przestrzenny, a efekty tego oddziaływania koncentrują się i uwidaczniają zawsze na pewnym obszarze. Tak więc wspieranie rozwoju infrastruktury jest jednym z najważniejszych działań podejmowanych przez władze różnych szczebli w celu pobudzania zarówno rozwoju danego obszaru, jak i podnoszenia jego konkurencyjności. Przyspieszenie tempa rozwoju stymuluje bowiem konkurencyjność i odwrotnie, wzrost konkurencyjności prowadzi do przyspieszenia tempa rozwoju.

\section{Cel, zakres i metodyka badań}

Głównym celem niniejszego opracowania było ukazanie znaczenia infrastruktury jako jednego z najistotniejszych czynników kształtujących konkurencyjność obszarów wiejskich. Ponadto wskazano na znaczenie jakie Unia Europejska w polityce regionalnej przypisuje infrastrukturze jako instrumentowi prokonkurencyjnemu. Rozważania zakończono wynikami badań dotyczących zmian, które miały miejsce w wyposażeniu infrastrukturalnym obszarów wiejskich Polski po wejściu Polski do Unii Europejskiej. Badaniami objęto wyposażenie wsi w kluczowe składniki infrastruktury, tj.: sieć wodociągową i kanalizacyjną, oczyszczalnie ścieków oraz sieć gazową i drogową.

Podstawą uzyskania liczbowych wartości wskaźników opisujących wybrane do badania składniki infrastruktury były dane udostępnione przez Główny Urząd Statystyczny w formie Banku Danych Lokalnych.

\section{Regionalna konkurencyjność obszarów wiejskich}

Konkurencyjność to zdolność do osiągania sukcesów w rywalizacji gospodarczej oraz do długotrwałego i efektywnego rozwoju. Konkurencyjność może być rozpatrywana w na różnych poziomach, jak i w różnych ujęciach, tj.: mikro (przedsiębiorstwa), mezo (regionu, branży) oraz makro (kraju, makroregionu). Początkowo pojęcie konkurencyjności odnoszono jedynie do przedsiębiorstw (Porter, 1980, 1990) i rozumiano jako sposób w jaki firmy rywalizują na rynku o przychylność klientów, co daje im szansę na bezpieczne i trwałe funkcjonowanie, czy też jako zdolność do sprawnego realizowania celów na rynkowej arenie konkurencji (Lenart, 2009; Stankiewicz, 2005). Dopiero później (lata 90. XX wieku) wraz ze wzrostem znaczenia regionu jako podmiotu ekonomicznego zaczęto pojęcie to rozpatrywać w kategoriach związanych z konkurencyjnością terytorialną (obszarową) i koncepcjami rozwoju regionalnego.

Rozpoczynając rozważania na temat konkurencyjności regionalnej należy zaznaczyć, iż mimo że konkurencyjność regionalną łączy się z atrakcyjnością (konkuruje się za pomocą eksponowania atrakcyjnych atrybutów), to nie można utożsamiać tych dwóch pojęć. Atrakcyjność ma bowiem charakter bierny, co oznacza, że atrakcyjny region po prostu posiada pewne cechy, które są istotne z punktu widzenia określonych grup interesariuszy. Z kolei konkurencyjność wiąże się z podjęciem przez region „gry”, której celem jest pokonanie rywali zabiegających o te same wartości (Kupiec, 2005; Kulczyk-Dynowska, 2013). 
Nie ma precyzyjnej i jednoznacznej definicji konkurencyjności regionu (Juchniewicz, Tomczyk, 2015). Te, które odnajduje się w literaturze przedmiotu cechuje dość duża ogólność. Konkurencyjność regionu definiowana jest jako przewaga danego regiony nad innymi regionami i jest wypadkową atrakcyjności oferty usługowej kierowanej do obecnych i potencjalnych użytkowników regionu, czyli mieszkańców, firm, inwestorów i gości (Klasik, 2001). Tak rozumiana konkurencyjność oznacza więc synergię zasobów materialnych $i$ intelektualnych wynikających między innymi $z$ infrastruktury, innowacyjności i przedsiębiorczości (Szymla, 2000). Konkurencyjność regionu to także jego zdolność do wytwarzania trwałego wzrostu wartości dodanej i wynikającego stąd wzrostu regionalnego dobrobytu. A prawdziwa konkurencyjność regionalna ma miejsce tylko wtedy, gdy osiągany jest trwały wzrost we wskaźnikach wykorzystania zasobów pracy, które przyczyniają się do zwiększenia ogólnego poziomu życia (Huggins, 2003). Również w definicji zaproponowanej przez Komisję Europejską (1999) konkurencyjność rozumiana jest jako zdolność przedsiębiorstw, gałęzi przemysłu, regionów i ponadnarodowych obszarów geograficznych wystawionych na konkurencję międzynarodową, do osiągania relatywnie wysokiego poziomu dochodów i zatrudnienia. Tak więc konkurencyjność regionu jest narzędziem i środkiem do osiągnięcia celu naczelnego, jakim jest uzyskanie stale rosnącego poziomu życia i społecznego dobrobytu.

Definiując konkurencyjność regionu należy również wyjaśnić ściśle z nią związane pojęcia pozycji i zdolności konkurencyjnej (Bronisz, 2013). Pozycja konkurencyjna, nazywana również konkurencyjnością wynikową, jak również konkurencyjnością ex post, określa miejsce regionu $\mathrm{w}$ rankingu regionów konkurujących $\mathrm{w}$ danym momencie. Tak więc wynika z poziomu konkurencyjności i dotyczy ujęcia statycznego, a może być wyrażana np. poziomem dochodu narodowego, efektywnością wykorzystania czynników wytwórczych czy pozycją w handlu zagranicznym. Z kolei zdolność konkurencyjna, zwana inaczej konkurencyjnością czynnikową, jak i konkurencyjnością ex ante, to dynamiczne ujęcie konkurencyjności, gdzie konkurencyjność pojmowana jest jako proces podlegający ciągłym zmianom (Łaźniewska, Chmielewski, Nowak, 2012).

Konkurencyjność terytorialna identyfikowana jest poprzez ocenę czynników, które charakteryzują wielkość, strukturę i wykorzystanie zasobów produkcyjnych, system społeczno-ekonomiczny, politykę ekonomiczną i uwarunkowania międzynarodowe. Analiza tych czynniki pozwala na określenie oczekiwanego w przyszłości poziomu konkurencyjności (Gorynia, 2010; Korol, Kusideł, Szczuciński, 2016).

Podsumowując, ogół definicji konkurencyjności regionu występujących w literaturze przedmiotu, zarówno krajowej, jak i zagranicznej, można podzielić na trzy podstawowe typy (Łaźniewska, Chmielewski i Nowak, 2012):

- $\quad$ wynikowe - bazują na rezultatach osiąganych przez gospodarkę oraz na ocenie pozycji konkurencyjnej osiąganej przez dane państwo czy region, nie analizując przy tym ich przyczyn,

- $\quad$ czynnikowe - skupiają się na ocenie źródeł konkurencyjności wpływających na przyszłą pozycję konkurencyjną regionu i warunkujących jego zdolność konkurencyjną,

- mieszane (czynnikowo-wynikowe) - są najbardziej kompleksowe, ponieważ uwzględniają zarówno obecny potencjał gospodarczy oraz pozycję konkurencyjną, jak i czynniki decydujące o potencjale wzrostu gospodarczego związanego ze zdolnością konkurencyjną. 
Konkurencyjność regionalną można rozpatrywać w dwóch aspektach tj. jako konkurowanie pośrednie i bezpośrednie. Konkurowanie pośrednie, które jest wyrażone i mierzone zdolnościami konkurencyjnymi firm zlokalizowanych w danym regionie, polega na podejmowaniu działań przez władze jednostek samorządu terytorialnego na rzecz poprawy warunków ich funkcjonowania. Ten rodzaj konkurowania oznacza istnienie warunków otoczenia regionalnego dla przedsiębiorstw w nim działających, które pozwalają na uzyskanie przez nie przewagi konkurencyjnej w zakresie nieobjętym ich kontrolą. Natomiast konkurowanie bezpośrednie to rywalizowanie jednostek terytorialnych o dostęp do różnego rodzaju korzyści zewnętrznych. Wąsko rozumiane korzyści to inwestycje zewnętrzne, lokalizacja instytucji, agend, czy imprez na terytorium regionu. Zaś w szerokim znaczeniu to wysoka jakość życia oraz rozwój społeczny i gospodarczy (Markowski, 1999; Łyżwa, 2014).

We współczesnych koncepcjach rozwoju terytorialnego konkurencyjność staje się dominującym parametrem. Prawidłowość ta, przy uwzględnieniu dzisiejszych warunków gospodarowania, pozwala na stwierdzenie, że obszary wiejskie ze względu na swoją pozycję (obszar i ludność) pełnią w tym procesie istotną rolę. Determinują nowe możliwości rozwoju i osiąganie wyższych pozycji konkurencyjnych przez jednostki samorządu terytorialnego.

W krajach rozwiniętych gospodarczo głównym narzędziem wzmacniania konkurencyjności obszarów wiejskich jest przejście od podejścia sektorowego do podejścia terytorialnego, co przyczynia się do powstania sytuacji, w której cele rozwoju obszarów wiejskich współgrają z celami rozwoju terytorialnego na poziomie lokalnym i regionalnym. We wzmacnianiu konkurencyjności obszarów wiejskich istotne znaczenie mają także różnego rodzaju inwestycje w nowe rodzaje działalności oraz wspieranie rozwoju nowych technologii. Ponadto w celu generowania nowych przewag konkurencyjnych na terenach niezurbanizowanych przy wykorzystaniu lokalnych uwarunkowań podejmowanych jest wiele działań związanych ze środowiskiem, kulturą, czy też polityką społeczną (Hadyński, 2015).

Obszary wiejskie mogą być konkurencyjne jeśli charakteryzują je określone atrybuty, które pozwalają osiągnąc sukces. Wśród tych atrybutów, które mogą być źródłem silnych stron danego obszaru najważniejszymi są (Styś, 1999):

- walory przyrodniczo-rolnicze,

- ziemia jako zasób, który stanowi źródło dochodu (działalność rolnicza), ale jest także miejscem lokalizacji działalności pozarolniczej,

- baza surowcowa dla przetwórstwa spożywczego zaspokajającego popyt żywnościowy,

- rynek pracy, który z jednej strony jest czynnikiem produkcji żywności, zaś z drugiej elementem konkurencji w stosunku do rynku pracy na obszarach zurbanizowanych,

- nowoczesne formy osadnictwa ludności związane z coraz większą emigracją mieszkaniową z miast na obszary wiejskie,

- nowe formy turystyki oparte na bezpośrednim kontakcie z przyrodą (agroturystyka),

- zainteresowanie ekologiczną zdrową żywnością, które rośnie wraz ze wzrostem zamożności społeczeństwa.

Czynniki wyznaczające konkurencyjność obszarów wiejskich są jednocześnie, zmieniającymi się w czasie, wraz ze zmianami w gospodarce, przyczynami wpływającymi na efektywne wykorzystanie ich szans rozwojowych. Należy zauważyć, że część tych czynników, w zależności od okoliczności, może być postrzegana jako zjawiska wpływające pozytywnie lub negatywnie na konkurencyjność danego obszaru, a część z nich trudno 
zmierzyć (efektywność administracji terytorialnej, usługi wspierające przedsiębiorczość, usługi infrastruktury społecznej, uwarunkowania instytucjonalne) (Łyżwa, 2016).

\section{Infrastruktura wśród determinant konkurencyjności obszarów wiejskich}

W szerokim ujęciu termin „infrastruktura” stosuje się do określenia zespołu obiektów, urządzeń i instytucji, które są konieczne do tworzenia, rozwoju czy prawidłowego funkcjonowania jakiegoś fragmentu systemu społecznego lub też tego systemu jako całości. Infrastruktura ma umożliwiać zaspokajanie potrzeb społeczeństwa w sferze jego działalności materialnej i niematerialnej (Ratajczak, 1999).

Infrastruktura jest jednym $\mathrm{z}$ podstawowych czynników determinujących trwały i zrównoważony rozwój obszarów wiejskich. Nie podlega wątpliwości związek pomiędzy wyposażeniem infrastrukturalnym danego obszaru, a jego rozwojem społecznogospodarczym. Znaczenie infrastruktury w ramach zachodzących procesów rozwojowych, zwłaszcza na poziomie regionalnym i lokalnym, wynika także z faktu, iż ma ona ogromny wpływ na budowanie konkurencyjności terenów wiejskich, przez co czyni je bardziej lub mniej atrakcyjnymi, a więc może sprzyjać korzystnym zmianom lub stanowić barierę rozwoju.

Relacje pomiędzy infrastrukturą a konkurencyjnością obszarów wiejskich mają charakter dwukierunkowy (Dolata, 2014):

- infrastruktura warunkuje uzyskanie odpowiedniego poziomu konkurencyjności obszarów wiejskich,

- chęć bycia konkurencyjnym wymusza na obszarach wiejskich rozwój infrastruktury na wysokim poziomie.

Wystarczająca, sprawna i dostarczająca wysokiej jakości usług infrastruktura decyduje o konkurencyjność danego obszaru. W wyniku rozwoju infrastruktury korzyści odnoszą, zarówno mieszkańcy w postaci m. in. zwiększenia poczucia bezpieczeństwa, oszczędności czasu, czy lepszego stan zdrowia i wyższego poziomu wykształcenia, jaki i przedsiębiorstwa uzyskując lepsze wyniki ekonomiczne.

Wyposażenie infrastrukturalne bezpośrednio kształtuje poziom tzw. atrybutów konkurencyjności, przez które często jest przedstawiany i omawiany problem konkurencyjności terytorialnej. Do tych atrybutów zalicza się przede wszystkim warunki życia, innowacyjność, informację i możliwości jej wykorzystania oraz kapitał ludzki. Wielość atrybutów konkurencyjności sprawia, że często nie można jednoznacznie określić wpływu skutków rozwoju danego elementu infrastruktury (np. sieci wodociągowej, sieci drogowej, systemu odprowadzanie i oczyszczanie ścieków, sieci teleinformatyczna, sieć energetycznej) na poziom konkurencyjności danego obszaru. Ocena ta zależy głównie od tego, na jakim polu region podejmie walkę konkurencyjną, czy będzie to rolnictwo, turystyka, czy może przemysł. Uznaje się, że wysoka specjalizacja regionów pozwala na osiągnięcie trwałej przewagi konkurencyjnej (Kulczyk-Dynowska, 2013; Łaźniewska, 2013).

Infrastruktura jest jednym z czynników, które tworzą tzw. potencjał konkurencyjny danego obszaru. Potencjał ten traktowany jest jako całokształt zasobów materialnych i niematerialnych stanowiących źródło kształtowania konkurencyjności. Ponadto 
infrastrukturze przypisuje się duże znaczenie jako czynnikowi określającemu zdolność konkurencyjną jednostki terytorialnej (Wiśniewski, Figurska, 2011).

Wśród mierników służących ocenie konkurencyjności danego terytorium znajdują się także te, które określają jego wyposażenie w podstawowe składniki infrastruktury (tzw. infrastruktury ciężkiej), a więc:

- długość, gęstość i dostępność do sieci wodociągowej, kanalizacyjnej i gazowej,

- długość i gęstość sieci drogowej,

- dostęp do usług świadczonych przez oczyszczalnie ścieków.

Kontynuując rozważania o roli infrastruktury $\mathrm{w}$ zwiększaniu konkurencyjności obszarów wiejskich należy podkreślić, że wraz z rozwojem cywilizacyjnym, postrzeganie infrastruktury uległo zmianie. Uznaje się, że możliwość zaspokajania podstawowych potrzeby związanych $\mathrm{z}$ usługami oferowanymi przez kluczowe elementy infrastruktury powinna być powszechna. Natomiast jej stan ocenia się już nie tylko za pomocą wskaźników określających jej ilość, ale przede wszystkim przez jakość i dostępność świadczonych przez nią usług (Dolata, Lira, 2009). W związku z tym podstawowe pomiary wyposażenia danego obszaru w infrastrukturę należy uzupełniać przez opinie podmiotów biorących udział w jej użytkowaniu i opierać się również na takich wskaźnikach jak:

- stopień zadowolenia z jakości usług,

- stopień zadowolenia z dostępu do usług.

- szkodliwość dla środowiska i człowieka,

- wydajność.

Jednym $\mathrm{z}$ priorytetów, $\mathrm{w}$ ramach polityki prowadzonej przez Unię Europejską w stosunku do obszarów wiejskich krajów starających się o akcesję do UE jaki i będących jej członkami, jest wspieranie rozwoju ich wyposażenia infrastrukturalnego. Efektami interwencji w obszarze infrastruktury ma być nie tylko podnoszenie atrakcyjności danego obszaru, wzrost poziomu oraz komfortu życia mieszkańców i wyrównywanie szans rozwojowych pomiędzy regionami i wewnątrz nich, ale także zwiększanie ich zdolności konkurencyjnej. Ponadto działania inwestycyjne w zakresie infrastruktury na poziomie lokalnym i regionalnym ma cechować komplementarność i spójność ze strategiami krajowymi. Inwestycje infrastrukturalne na obszarach wiejskich były i są współfinansowane, także w Polsce, ze środków pomocowych Unii Europejskiej pochodzących m. in. z funduszy przedakcesyjnych, środków z kolejnych okresów programowania (2004-2006, 2007-2013, 2014-2020) oraz Programów Life i Life+.

Kończąc omawianie roli infrastruktury jako determinanty konkurencyjności obszarów wiejskich należy jeszcze dodać, nie deprecjonując pozytywnej roli infrastruktury $\mathrm{w}$ analizowanych procesach, że niekiedy zmiany zachodzące $\mathrm{w}$ infrastrukturze mogą wywoływać także następstwa niepożądane. Wśród nich podstawowym niepożądanym efekt rozwoju infrastruktury jest tzw. „efekt tunelu”, czyli sytuacja kiedy rozwój infrastruktury sprowadza się głównie do przedsięwzięć zwiększających tranzytowe znaczenie danego obszaru. Efekt ten w minimalnym stopniu wywołuje pozytywne efekty zewnętrzne, a często jest źródłem istotnych lokalnych niekorzyści zewnętrznych (Ratajczak, 2002). 


\section{Zmiany w wyposażeniu obszarów wiejskich w Polsce w podstawowe składniki infrastruktury gospodarczej po wejściu Polski do Unii Europejskiej}

W niniejszej części artykułu przedstawiono zmiany jakie miały miejsce w wyposażeniu infrastrukturalnym obszarów wiejskich po wejściu Polski do struktur Unii Europejskiej, tj. w latach 2004-2015. Analizie poddano elementy infrastruktury stanowiące tzw. minimum zagospodarowania infrastrukturalnego, a więc:

- sieć wodociągową,

- sieć kanalizacyjną,

- oczyszczalnie ścieków,

- sieć gazową,

- sieć drogową.

W analizowanym w pracy okresie długość rozdzielczej sieci wodociągowej działającej na obszarach wiejskich Polski wzrosła o 45,6 tys. km, czyli o niespełna 25\% (tab. 1). Średnio w każdym z badanych lat długość sieci zwiększała się o 2,1\%. W 2015 r. na $100 \mathrm{~km}^{2}$ powierzchni terenów wiejskich przypadało 74,9 km wodociągu (w $2004 \mathrm{r}$. analogiczna wielkość była mniejsza o $15,8 \mathrm{~km}$ ). Przyrostowi długości sieci towarzyszył wzrost liczby odbiorców dostarczanej w ten sposób wody. W ciągu dwunastu lat liczba połączeń wodociągowych do budynków mieszkalnych zwiększyła się w badanym okresie o 716656 szt., tj. o 27\%. Wraz z rozwojem sieci wodociągowej rosła również liczba osób korzystających z jej usług. W 2004 r. możliwość poboru wody z wodociągu sieciowego miało $71,3 \%$ mieszkańców polskiej wsi, a w $2015 \mathrm{r}$. odsetek ten ukształtował się na poziomie wyższym o 13,4 p. proc. (rys. 1).

Tabela 1. Dynamika zmian długości sieci wodociagowej i kanalizacyjnej na obszarach wiejskich Polski w latach 2004-2015

Table 1. Dynamics of changes in the length of water and sewage networks in rural areas of Poland in 2004-2015

\begin{tabular}{c|cccc}
\hline \multirow{2}{*}{ Lata } & \multicolumn{2}{|c}{ Sieć wodociągowa } & \multicolumn{2}{c}{ Sieć kanalizacyjna } \\
& długość [tys. km] & rok poprzedni $=100$ & długość [tys. km] & rok poprzedni $=100$ \\
\hline 2004 & 185,4 & - & 32,4 & 113,6 \\
2005 & 190,7 & 102,9 & 36,8 & 109,5 \\
2006 & 195,5 & 102,5 & 40,3 & 107,9 \\
2007 & 200,3 & 102,5 & 43,5 & 107,8 \\
2008 & 204,2 & 101,9 & 46,9 & 107,7 \\
2009 & 207,4 & 101,6 & 50,5 & 110,1 \\
2010 & 211,9 & 102,2 & 55,6 & 114,4 \\
2011 & 216,3 & 102,1 & 63,6 & 109,7 \\
2012 & 220,0 & 101,7 & 69,8 & 107,9 \\
2013 & 223,5 & 101,6 & 75,3 & 108,1 \\
2014 & 226,8 & 101,5 & 81,4 & 107,6 \\
2015 & 231,0 & 101,9 & 87,6 & \\
\hline
\end{tabular}

Źródło: opracowanie własne na podstawie: Bank Danych Lokalnych, GUS, 2017.

W latach 2004-2015 na obszarach wiejskich miał miejsce znacznie szybszy, w porównaniu z rozwojem sieci wodociągowej, rozwój sieci kanalizacyjnej (tab. 1). 
Średnioroczne tempo zmian długości rozdzielczej sieci kanalizacyjnej wynosiło 9,7\%, co w liczbach bezwzględnych dało prawie trzykrotny przyrost jej długości (z 32,4 tys. km w 2004 r. do 87,6 tys. km w 2015 r.). Wzrosła również gęstość sieci, z 11,1 km przypadających na $100 \mathrm{~km}^{2}$ do $30,1 \mathrm{~km} / 100 \mathrm{~km}^{2}$.W wyniku tak szybkiego wzrostu długości sieci kanalizacyjnej rosła też liczba jej połączeń do budynków mieszkalnych -z 522,2 tys. w 2004 r. do 1380,9 tys. w 2015 r. tj. ponad dwu i półkrotnie. Średnio w każdym z badanym lat wzrastała ona o $9,8 \%$. Duże ożywienie procesów inwestycyjnych w sieć odprowadzającą ścieki znalazło swoje odzwierciedlenie nie tylko w przyroście długości sieci i liczby jej połączeń do budynków mieszkalnych, ale również w systematycznym, postępującym z roku na rok wzroście liczby ludności korzystającej ze świadczonych przez nią usług. Kiedy jeszcze w 2004 r. odsetek mieszkańców polskiej wsi obsługiwanych przez sieć kanalizacyjną wynosił 17,3\% ogółu osób tam zamieszkujących, to w 2015 r. jego wartość kształtowała się na poziomie wyższym o 21,9 p. proc. (rys. 1). Należy jednak zauważyć, że mimo iż w latach 2004-2015 sieć kanalizacyjna na obszarach wiejskich rozwijała się bardzo dynamicznie, to nadal nie obsługuje nawet połowy ich mieszkańców. Niedorozwój sieci kanalizacyjnej jest szczególnie widoczny na tle znacznie lepiej rozwiniętej sieci wodociągowej. W 2015 r. sieć kanalizacyjna była prawie trzykrotnie krótsza od sieci wodociągowej, a połączenia kanalizacyjne do budynków mieszkalnych stanowiły jedynie $41 \%$ połączeń wodociągowych (tab. 1, rys. 1).

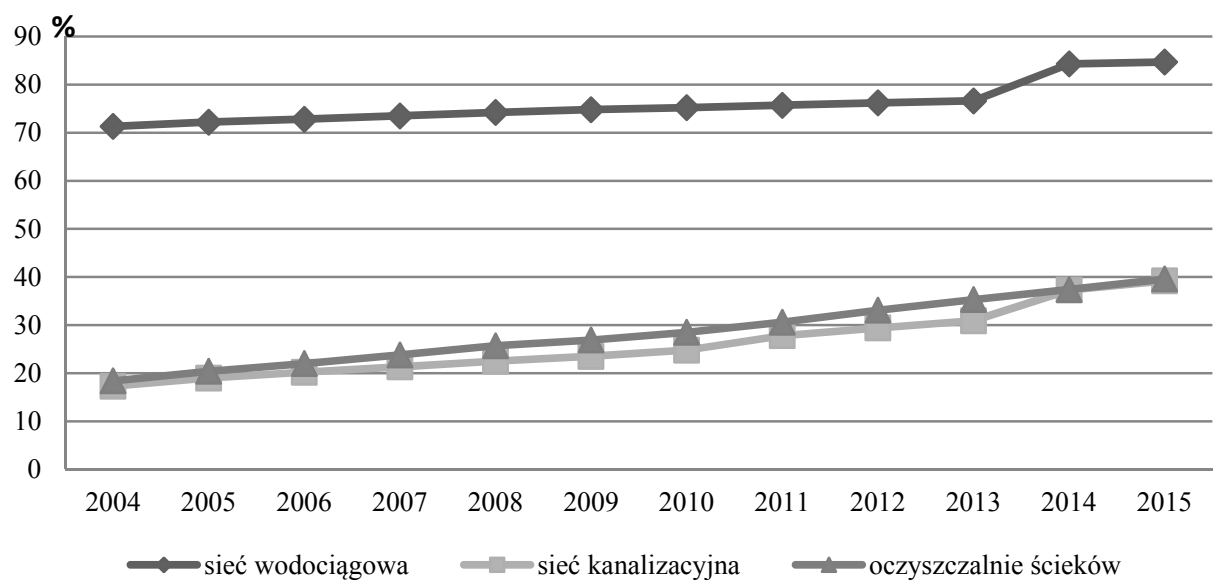

Rys. 1. Ludność korzystająca z sieci wodociągowej, sieci kanalizacyjnej i oczyszczalni ścieków \% ogólnej liczby ludności zamieszkującej obszary wiejskie Polski w latach 2004-2015

Fig. 1. Population using the water supply network, sewage network and sewage treatment plants in $\%$ of the total population living in rural areas of Poland in 2004-2015

Źródło: opracowanie własne na podstawie: Bank Danych Lokalnych, GUS, 2017.

Oczyszczalnie ścieków są obok sieci wodociągowej i sieci kanalizacyjnej niezbędnym elementem ochrony wód i ochrony sanitarnej ludności. W latach 2005-2015 na obszarach wiejskich wybudowano 523 oczyszczalnie ścieków (w 2005 r. było ich 2044, a w 2015 r. 2567). Wraz ze wzrostem liczby oczyszczalni następował systematyczny wzrost liczby mieszkańców polskiej wsi przez nie obsługiwanych, z 18,4\% w 2004 r. do 39,6\% 
w 2015 r. Średnioroczne tempo zmian liczby ludności wiejskiej korzystającej z usług zbiorczych oczyszczalni ścieków wynosiło 7,6\%. Podkreślenia wymaga również fakt, że we wszystkich badanych latach udziały ludności wiejskiej korzystającej z usług oczyszczalni ścieków i usług sieci kanalizacyjnej ścieków w ogólnej liczbie ludności kształtowały się na zbliżonym poziomie, co w kontekście ochrony środowiska jest zjawiskiem ze wszech miar pozytywnym (rys. 1).

Lata 2004-2005 były okresem systematycznego, choć dość powolnego, rozwoju rozdzielczej sieci gazowej na obszarach wiejskich w Polsce. Jej długość wzrosła o 12,9 tys. km, zaś liczba jej połączeń do budynków mieszkalny o 204 tys., co w obu przypadkach oznacza wzrost o około $23 \%$ (tab. 2). Średnio w każdym z badanych lat długość sieci gazowej rosła o $2 \%$, zaś liczba jej połączeń o 1,8\%. Zagospodarowanie obszarów wiejskich siecią gazową zwiększyło się z $19 \mathrm{~km} / 100 \mathrm{~km}^{2}$ ich powierzchni do $23,4 \mathrm{~km} / 100 \mathrm{~km}^{2}$. W $2004 \mathrm{r}$. z usług sieci gazowej korzystało 2619 tys. osób, co stanowiło 17,8\% mieszkańców wsi, zaś w 2015 r. było to 3446,4 tys. osób tj. $22,6 \%$.

Tabela 2. Dynamika zmian długości sieci gazowej i sieci drogowej na obszarach wiejskich Polski w latach $2004-$ 2015

Table 2. Dynamics of changes in length of gas and road network in rural areas of Poland in 2004-2015

\begin{tabular}{l|cccc}
\hline \multirow{2}{*}{ Lata } & \multicolumn{2}{|c}{ Sieć gazowa } & \multicolumn{2}{c}{ Sieć drogowa } \\
& długość [tys. km] & rok poprzedni $=100$ & długość [tys. km] & rok poprzedni=100 \\
\hline 2004 & 55,3 & - & 188,3 & 1,01 \\
2005 & 56,4 & 102,0 & 189,2 & 1,00 \\
2006 & 58 & 102,8 & 190,5 & 1,01 \\
2007 & 59,1 & 101,9 & 192,8 & 1,01 \\
2008 & 60,1 & 101,7 & 194,6 & 1,01 \\
2009 & 61,1 & 101,7 & 200,1 & 1,03 \\
2010 & 61,8 & 101,1 & 203.8 & 1,02 \\
2011 & 62,9 & 101,8 & 209,0 & 1,03 \\
2012 & 64,1 & 101,9 & 209,3 & 1,00 \\
2013 & 65,4 & 102,0 & 211,3 & 1,01 \\
2014 & 66,6 & 101,8 & 214,2 & 1,01 \\
2015 & 68,2 & 102,4 & 216,7 & 1,01 \\
\hline
\end{tabular}

Źródło: opracowanie własne na podstawie: Bank Danych Lokalnych, GUS, 2017.

Sieć drogowa, a przede wszystkim jej część, którą tworzą drogi o twardej nawierzchni, jest jednym $\mathrm{z}$ najistotniejszych elementów infrastruktury gospodarczej na obszarach wiejskich. W analizowanym w pracy okresie następował stały, chociaż niewielki rozwój sieci drogowej. Średnio ich długość każdego roku zwiększała się o 1,3\%, co dało przyrost równy 28,4 tys. km (z 188,3 tys. km w roku 2004 do 216,7 tys. km w 2015 r.). Wraz ze wzrostem długości sieci drogowej zwiększała się również jej gęstość. Kiedy w pierwszym roku badania na $100 \mathrm{~km}^{2}$ powierzchni obszarów wiejskich przypadało $64,4 \mathrm{~km}$ dróg, to w ostatnim roku analogiczna wielkość wynosiła $74,5 \mathrm{~km} / 100 \mathrm{~km}^{2}$ (tab. 2). 


\section{Podsumowanie}

Przeprowadzone w artykule rozważania i badania pozwalają na sformułowanie następujących wniosków:

1. Obszary wiejskie są uczestnikiem zachodzących we współczesnym świecie procesów rozwojowych, których nieodłącznym elementem jest ciągły udział w rywalizacji o dostęp do korzyści zewnętrznych oraz podejmowanie działań na rzecz poprawy warunków funkcjonowania podmiotów gospodarczych. W ujęciu terytorialnym konkurencyjność oznacza zdolność przystosowywania się danego obszaru (konkurencyjność regionalna) do zmieniających się warunków, a przede wszystkim do poprawy jego pozycji konkurencyjnej w stosunku do innych obszarów.

2. Jednym $\mathrm{z}$ najważniejszych elementów kształtujących atrybuty konkurencyjności obszarów wiejskich zarówno na poziomie regionalnym, jak i na poziomie lokalnym jest infrastruktura. Infrastruktura warunkuje uzyskanie odpowiedniego poziomu konkurencyjności, a chęć bycia konkurencyjnym wymusza rozwój infrastruktury na wysokim poziomie. Znaczenie infrastruktury w procesach podnoszenia konkurencyjności zostało również docenione w polityce Unii Europejskiej dotyczącej spójności ekonomicznej i społecznej oraz wyrównywania różnic w poziomach życia i rozwoju pomiędzy poszczególnymi obszarami administracyjnymi czy też geograficznymi.

3. W latach 2004-2015 na obszarach wiejskich w Polsce miał miejsce znaczący rozwój ich wyposażenia w podstawowe elementy infrastruktury gospodarczej. Długość sieci wodociągowej wzrosła o $25 \%$, a liczba jej połączeń do budynków mieszkalnych o $27 \%$. Prawie trzykrotnie zwiększyła się długość sieci kanalizacyjnej, a dwu i półkrotnie liczba jej podłączeń do budynków. Wraz z liczbą inwestycji, których efektem były 523 oczyszczalnie ścieków, odsetek mieszkańców wsi obsługiwanych przez oczyszczalnie zwiększył się o 21 p. proc.

4. Na polskiej wsi nadal potrzebne są działania w obszarze rozwoju infrastruktury. Dalszych inwestycji wymaga przede wszystkim zagospodarowanie obszarów wiejskich w urządzenia infrastruktury świadczącej usługi odprowadzania i oczyszczania ścieków oraz dostarczania gazu. W 2015 r. sieć kanalizacyjna na obszarach wiejskich była ponad dwu i półkrotnie krótsza niż sieć wodociągowa, a z jej usług miało możliwość korzystania tylko 39\% ogółu mieszkańców. Liczba ludności obsługiwanej przez oczyszczalni ścieków wynosiła 6049 tys., co stanowiło niespełna 40\% ludności wiejskiej. Wolne tempo rozwoju cechowało rozdzielczą sieć gazową, która dostarczała gaz jedynie do $23 \%$ mieszkańców terenów wiejskich.

\section{Literatura}

Bronisz, U. (2013). Metody badania konkurencyjności regionów, Studia KPZK PAN, Tom CL, Warszawa, 36-38. Dolata, M. (2014). Infrastruktura społeczna jako czynnik kształtujący konkurencyjność regionu. Marketing $i$ Rynek $10,35-43$.

Dolata, M., Lira, J. (2009). Zróżnicowanie infrastruktury gospodarczej obszarów wiejskich woj. wielkopolskiego, Wiadomości Statystyczne, 12, 66-80.

Gorynia, M. (2010). Teoretyczne aspekty konkurencyjności. W: M. Gorynia, E. Łaźniewska (red.), Kompendium wiedzy o konkurencyjności, Wyd. Naukowe PWN, Warszawa, 53-54.

Hadyński, J. (2015). Regionalna konkurencyjność obszarów wiejskich, Wyd. Uniwersytetu Przyrodniczego w Poznaniu, Poznań. 
Huggins, R. (2003). Creating a UK Competitiveness Index; Regional and Local Benchmarking, Regional Studies, $37(1), 89-96$.

Juchniewicz, M., Tomczyk, U. (2015). Kapitał intelektualny podmiotów gospodarczych a konkurencyjność regionów, Wyd.: Instytut Badań i Analiz Grupa OSB, Olsztyn.

Klasik, A. (2001). Konkurencyjność województwa śląskiego na tle innych regionów. Ujęcie syntetyczne. W: Województwo śląskie. Integracja, konkurencyjność, nowe inicjatywy. II Śląskie Forum Rozwoju Lokalnego i Regionalnego, Wyd. AE, Górnośląska Wyższa Szkoła Przedsiębiorczości, Katowice.

Komisja Europejska (1999). The Sixth Periodic Report on the Regions. Office for Official Publications of the European Communities, Luxembourg.

Korol, J., Kusideł, E., Szczuciński, P. (2016). Przedsiębiorczość, produktywność i konkurencyjność regionów Polski, Wyd. Adam Marszałek, Toruń

Kulczyk-Dynowska, A. (2013). Rozwój regionalny na obszarach chronionych, Wyd. Uniwersytetu Przyrodniczego we Wrocławiu, Wrocław.

Kupiec, L. (2005). Atrakcyjność regionu a sposób rozprzestrzeniania się innowacji i rozwoju społecznogospodarczego. W: A. Kopczuk, M. Proniewski (red.), Atrakcyjność inwestycyjna regionu, Wyd. Wyższej Szkoły Zarządzania i Finansów w Białymstoku, Białystok.

Lenart, A. (2009), System ERP jako narzędzie poprawy konkurencyjności przedsiębiorstw. W: S. Lachiewicz, M. Matejuk (red.), Konkurencyjność jako determinanta rozwoju przedsiębiorstwa, Wyd. Politechniki Łódzkiej, Łódź, 257-266.

Łaźniewska, E. (2013). Konkurencyjność regionalna w czasie i przestrzenie na przykładzie polskich regionów, Wyd. Uniwersytetu Ekonomicznego w Poznaniu, Poznań.

Łaźniewska, E., Chmielewski, R, Nowak, P (2012). Definicje, modele i studia nad regionalną konkurencyjnością. W: E. Łaźniewska, M. Gorynia (red.), Konkurencyjność regionalna. Koncepcje - strategie - przykłady, Wyd. Naukowe PWN, Warszawa.

Łyżwa, E. (2004). Innowacyjność przedsiębiorstw a konkurencyjność regionów, Wyd. Uniwersytetu Jana Kochanowskiego, Kielce, 55-58.

Markowski, T. (1999). Zarządzanie rozwojem miast, PWN, Warszawa.

Porter, M. E. (1991). Competitive Advantage of Nations, Macmillan, London.

Porter, M. E. (1980). Competitive Strategy: Techniques for Analyzing Industries and Competitors, The Free Press, New York.

Ratajczak, M. (1999). Infrastruktura w gospodarce rynkowej, Wyd. Akademii Ekonomicznej w Poznaniu.

Ratajczak, M. (2002). Znaczenie infrastruktury w procesach globalizacji i integracji regionalnej. W: E. Skawińska (red.), Problemy wdrażania strategii rozwoju województwa wielkopolskiego, Wyd. Polskiego Towarzystwa Ekonomicznego Oddział w Poznaniu, Poznań.

Stankiewicz, M. J. (2005). Konkurencyjność przedsiębiorstwa: budowanie konkurencyjności przedsiębiorstwa w warunkach globalizacji, Dom Organizatora, Toruń

Styś, S. (1999). Problematyka konkurencyjności obszarów wiejskich. W: M. Klamut (red.), Konkurencyjność regionów, Wyd. Akademii Ekonomicznej im. Oskara Langego we Wrocławiu, Wrocław.

Szymla, Z. (2000). Determinanty rozwoju regionalnego, Zakład Narodowy im. Ossolińskich Wydawnictwo, Wrocław.

Wiśniewski, E., Figurska, I. (2011). Wybrane metody oceny poziomu konkurencyjności powiatów pomorza środkowego. W: W. Deluga, J. Dyczkowska (red.), Marketing terytorialny - konkurencyjność regionów, przedsiębiorstw a ochrona środowiska, Wyd. Uczelniane Politechniki Koszalińskiej, Koszalin. 